\title{
Enterprise Value Evaluation: Application and Improvement based on Cash Flow Model and Economic Value Added Model
}

\author{
Wu Na ${ }^{1, a}$, Rao Qian ${ }^{2, b}$ \\ ${ }^{1}$ College of Economics and Management, Hebei University of Science and Technology, \\ ShiJiaZhuang HeBei 050018, China \\ ${ }^{2}$ College of Economics and Management, Hebei University of Science and Technology, \\ ShiJiaZhuang HeBei 050018, China \\ a1624402503@qq.com, braoqian100@163.com
}

Keywords: Economic value added, Free cash flow, Enterprise value, Improvement.

\begin{abstract}
The maximization of enterprise value is the goal of enterprise financial strategy, and it can analyze the future development of enterprise from the perspective of enterprise value. Here, the economic value added model and the free cash flow discount model applied to the evaluation of enterprise strategy can make the enterprise comprehensively analysis the company's future development from the perspective of the value of the company. Through the two models in detail, uses the basic theory and model analysis of two models to assess the instance of company strategy, which the results illustrate that the two models are equivalent. Finally, it illustrates that the defects of the two methods and puts forward some improvement suggestions.
\end{abstract}

\section{Introduction}

Free cash flow from the beginning of the article American scholars Jensen (Jenson) in 1986, proposed the concept of free cash flow[1], free cash flow that is that part of the enterprise to meet the cash flow of the funds required for all projects NPV greater than zero after. It refers to the amount of inflows and outflows over a certain period of corporate cash and cash equivalents, including cash flow from operating activities, cash flow from financing activities and cash flows from investing activities generated. Corporate free cash flow formula is expressed as:

Enterprise Free Cash Flow $=$ earnings before interest and tax $\times(1-$ Tax rate $)+$ Depreciation Capital expenditures - Net increase in working capital

Economic Value Added also known as economic profit, is first proposed by the United States management consulting firm Stern Stewart in the early 1980s. It is not only an important indicator of economic condition and evaluation of enterprise management level, but also in the company's strategic planning and decision-making also had a crucial role. Economic value added is a kind of performance evaluation index that widely used in inside and outside. As one of the useful tools for business management, economic value added can fully measure of business performance, reflecting all aspects of the management of value. Economic value added expression:

Economic value added $=$ Net operating profit after tax - Capital total cost

Currently, the enterprise value assessment has become a tool of investment decisions, mergers and acquisitions, credit management, and enterprise value management. It is plays an important role in preventing investment risks and improves enterprise management efficiency.

In this view, there are many issues in the process of enterprise value assessment, analysis the calculation results from the point of view of cash flow and economic value added, and the results reveal that the two models are equivalent. Finally, the model is improved by taking into account the inflation rate.

\section{The Theory of Enterprise Value Model Brief}

\section{Overview of the Discounted Free Cash Flow.}

Discounted free cash flow that is the discounted cash flow method (referred to as DCF) through selecting the discount rate, and can make the future cash flow equivalent to the present value, the 
key to this method is to forecast future cash flows and the selection of discount rate. Companies decided to select what kind of discount rate determined by the degree of risk of future, with the degree of risk of alters, the discount rate will also change[2].

The period of free cash flow forecasted. The formula is:

$$
\begin{aligned}
& \text { The present value of cash flow }=\sum_{t=1}^{\mathrm{n}} \frac{F C F F}{(1+W A C C)^{t}} \\
& \qquad W A C C=K e \times E /(D+E)+K d \times(1-t) \times D /(D+E) \\
& K e=R f+\beta \times(R \mathrm{~m}-R f)
\end{aligned}
$$

Among: FCFEt is the after tax cash flow of the year t;

WACC is the Weighted Average Cost of Capital in the enterprise stable growth phase;

$\mathrm{Ke}$ is the Cost of Equity Capital;

$\mathrm{Kd} /(1-t)$ is the after-tax cost of debt;

$\mathrm{E} /(\mathrm{D}+\mathrm{E})$ is the owners' equity accounting for the sum of interest debt and owner's equity;

$\mathrm{D} /(\mathrm{D}+\mathrm{E})$ is interest-bearing debt as a percentage of total interest-bearing debt to equity ratio;

$R \mathrm{~m}-R f$ is the Market portfolio risk premium, $\beta$ is the measure of the risk of a stock to the entire market.

The followed up of final value. Follow-up of the final value $=\frac{F C F F n+1}{W A C C-g}$

Among: FCFFn +1 is the after tax cash flow of the year $t+1$;

$\mathrm{g}$ is for the enterprise stable growth.

\section{Economic Value Added Model Overview.}

Economic value added includes all capital costs. economic value added $=$ Net operating profit after tax - initial investment capital $\times$ weighted average cost of capital.

\section{Empirical Study}

The empirical analysis of an enterprise is used to forecast the development of 2016 - 2020 the resulting value is applied to the future development in the process of enterprise. According to the prediction of the development status of enterprises now the annual revenue growth rates were $12 \%$, $12 \%, 10 \%, 10 \%, 9 \%$. After 2020 the enterprise entered a period of stable development, assuming that the growth rate of $g$ was $6 \%$. The data used in this article are in additionally to the millions of units in table 2.

\section{Discounted Cash Flow Model Calculations.}

The data used from that enterprise's financial statements and annual reports, which calculate the $\beta$ value is through the monthly stock returns of enterprises $\mathrm{k} 1$ and the corresponding market index monthly return rate, do linear regression:

$$
K 1=\alpha+\beta \times K 2
$$

The data used in the article are based on millions of units in addition to the table 2 .

Forecast Financial data are by the method revenue ratio method. According to the operating conditions of enterprises in 2013-2014, as it can be seen from Table in 2014 operating income growth rate was $11.9 \%, 9.4 \%$ in 2015 . At the same time, combined with the current situation of enterprise market development and national policy. There will be a small increase in income since 2015. In 2013-2015 operating costs accounted for an increase in operating income, after 2015 will be decreased. Since the depreciation will decline that incomes will rise, therefore the depreciation percentage of revenue will decline. Finally, it can predict other financial data through revenue forecast. 
Table 1 The Primal Financial Data Of 2013-2015

\begin{tabular}{|c|c|c|c|}
\hline Year & 2013 & 2014 & 2015 \\
\hline Prime operating revenue & 1011.5 & 1132.1 & 1238.0 \\
\hline Operating costs & 812.2 & 924.2 & 1016.1 \\
\hline Capital expenditures & 129.9 & -6.9 & 38.4 \\
\hline $\begin{array}{c}\text { Selling expenses + } \\
\text { Administrative expense }\end{array}$ & 100.5 & 114.9 & 139.3 \\
\hline Finance expense & 37.8 & 43.7 & 28.9 \\
\hline Depreciation and amortization & 43.1 & 69.5 & 91.4 \\
\hline Working capital & 550.7 & 715.3 & 651.0 \\
\hline Construction in progress & 98.2 & 68.0 & 73.3 \\
\hline Bad debt reserves & 12.3 & 15.2 & 17.5 \\
\hline Inventory falling price reserves & 0.56 & 1.9 & 2.6 \\
\hline Debt capital & 531.8 & 314.3 & 458.7 \\
\hline Equity capital & 83.2 & 82.7 & 107.8 \\
\hline
\end{tabular}

Table 2 Financial Indicators Forecast Proportion

\begin{tabular}{|c|c|c|c|c|c|c|}
\hline Year & 2015 & 2016 & 2017 & 2018 & 2019 & 2020 \\
\hline Operating costs & 0.82 & 0.80 & 0.80 & 0.80 & 0.80 & 0.80 \\
\hline Selling expenses & 0.06 & 0.06 & 0.06 & 0.06 & 0.06 & 0.06 \\
\hline Administrative expense & 0.04 & 0.05 & 0.05 & 0.05 & 0.05 & 0.05 \\
\hline Finance expense & 0.02 & 0.02 & 0.02 & 0.02 & 0.02 & 0.02 \\
\hline $\begin{array}{c}\text { Depreciation and } \\
\text { amortization }\end{array}$ & 0.07 & 0.06 & 0.06 & 0.06 & 0.06 & 0.06 \\
\hline
\end{tabular}

Table 3 Net Investment Prediction Table

\begin{tabular}{|c|c|c|c|c|c|}
\hline Year & 2016 & 2017 & 2018 & 2019 & 2020 \\
\hline Working capital & 693.3 & 776.5 & 854.14 & 939.6 & 1024.1 \\
\hline Working capital Increase & 82.2 & 83.2 & 77.6 & 85.4 & 84.6 \\
\hline Capital expenditures & 34.6 & 38.8 & 42.7 & 37.6 & 40.9 \\
\hline Net investment & 116.8 & 122.1 & 120.3 & 122.9 & 125.5 \\
\hline
\end{tabular}

Table 4 Forecast profit statement

\begin{tabular}{|c|c|c|c|c|c|}
\hline Year & 2016 & 2017 & 2018 & 2019 & 2020 \\
\hline Revenue & 1386.6 & 1552.9 & 1708.2 & 1879.1 & 2048.2 \\
\hline Less: Operating costs & 1109.2 & 1242.3 & 1366.6 & 1503.2 & 1638.5 \\
\hline Sales tax & 13.8 & 15.5 & 17.0 & 18.7 & 20.4 \\
\hline Selling expenses & 83.2 & 93.1 & 102.5 & 112.7 & 122.8 \\
\hline Administrative expense & 69.3 & 77.6 & 85.4 & 93.9 & 102.4 \\
\hline Finance expense & 27.7 & 31.0 & 34.1 & 37.5 & 40.9 \\
\hline Profit from operation & 83.1 & 93.1 & 102.5 & 112.7 & 122.8 \\
\hline Less: Income tax & 20.7 & 23.2 & 25.6 & 28.1 & 30.7 \\
\hline Net profit & 62.3 & 69.8 & 76.8 & 84.5 & 92.1 \\
\hline
\end{tabular}

Table 5 Free cash flow prediction table

\begin{tabular}{|c|c|c|c|c|c|}
\hline Year & 2016 & 2017 & 2018 & 2019 & 2020 \\
\hline Profit from operation & 62.4 & 69.8 & 76.8 & 84.5 & 92.2 \\
\hline Add: After-tax interest expense & 18.7 & 20.9 & 23.1 & 25.4 & 27.7 \\
\hline Depreciation and amortization & 83.2 & 93.2 & 102.5 & 112.7 & 122.9 \\
\hline NOPAT & 164.3 & 184.0 & 202.4 & 222.6 & 242.7 \\
\hline Less: Net investment & 116.8 & 122.0 & 120.3 & 122.9 & 125.5 \\
\hline FCF & 47.7 & 62.8 & 82.4 & 99.3 & 117 \\
\hline
\end{tabular}

The risk-free rate of return in this article takes Treasury ten-year coupon rate of $3.4 \%$. Take the risk premium $10.49 \%, \beta$ takes 1.1 , Equity ratio based on the historical average, is the five-year bank lending rate. Which is : risk free rate is $3.4 \%, r m=10.49 \%, \beta=1.1$, the owners' equity accounting for the sum of interest debt and owner's equity is $60 \%$, the interest-bearing debt as a percentage of total interest-bearing debt to equity ratio is $40 \%$. The after-tax cost of debt is $4.75 \%$. Therefore: the 
cost of equity capital $=3.4 \%+1.1 \times(10.49 \%-3.4 \%)=11.2 \%$. The weighted average cost of capital in the enterprise stable growth phase $=4.75 \% \times 40 \%+11.2 \% \times 60 \%=8.62 \%$.

Table 6 Value Estimation Table

\begin{tabular}{|c|c|c|c|c|c|c|}
\hline Year & 2016 & 2017 & 2018 & 2019 & 2020 & final value \\
\hline FCF & 47.7 & 62.8 & 82.3 & 99.3 & 117.3 & 4741.0 \\
\hline Discount factor & 0.9206 & 0.8475 & 0.7803 & 0.7183 & 0.6613 & 0.6613 \\
\hline Present value & 43.6 & 52.5 & 64.0 & 71.6 & 77.5 & 3135.0 \\
\hline
\end{tabular}

\section{The Calculations Economic Value Added Model.}

The driving factor of enterprise value under the economic value added model is the rate of return, growth rate and capital cost.

Table 7 Net operating profit after tax

\begin{tabular}{|c|c|c|c|c|c|}
\hline Year & 2016 & 2017 & 2018 & 2019 & 2020 \\
\hline Net profit & 81.1 & 90.8 & 99.9 & 109.9 & 119.8 \\
\hline Minority interests & 69.3 & 77.6 & 85.4 & 93.9 & 102.4 \\
\hline Less: Deferred tax assets & 50.9 & 48.9 & 46.5 & 44.2 & 42.3 \\
\hline Increase in various reserve & 1.8 & 1.8 & 1.7 & 1.8 & 1.8 \\
\hline NOPAT & 101.3 & 121.4 & 140.4 & 161.5 & 181.7 \\
\hline
\end{tabular}

Table 8 Calculation of economic value added

\begin{tabular}{|c|c|c|c|c|c|}
\hline Year & 2016 & 2017 & 2018 & 2019 & 2020 \\
\hline Debt capital & 526.9 & 590.1 & 649.1 & 714.0 & 778.3 \\
\hline Equity capital & 180.2 & 241.8 & 262.0 & 284.2 & 306.2 \\
\hline Bad debt reserves & 13.8 & 15.5 & 17.0 & 18.7 & 20.4 \\
\hline Inventory falling price reserves & 1.38 & 1.55 & 1.70 & 1.88 & 2.05 \\
\hline Construction in progress & 97.0 & 108.7 & 119.5 & 131.5 & 143.3 \\
\hline Total capital & 625.3 & 740.3 & 810.4 & 887.4 & 963.7 \\
\hline weighted average cost of capital & $8.62 \%$ & $8.82 \%$ & $8.62 \%$ & $8.62 \%$ & $8.62 \%$ \\
\hline economic value added & 47.4 & 57.0 & 70.6 & 85.0 & 98.6 \\
\hline Present value & 43.7 & 48.8 & 55.1 & 61.0 & 65.2 \\
\hline
\end{tabular}

Among: FCFFt is the after tax cash flow of the year t; the stable phase economic value added value is 3991.4Million Yuan. The present value of economic value added in the stable period is 2639 Million Yuan.

Enterprise Value $=$ Opening total capital + present value of economic value added = $513380792.1+2913806989.58=3427187781.67$ Yuan .

\section{Analysis and Conclusions.}

Firstly, through the analysis of the above method, cash flow discount model and the economic value added model are equivalent to the enterprise value. Economic value added discount model and the enterprise free cash flow discount are based on the same assumptions in order to calculate the value of enterprises. These assumptions are mainly about:

At any stage of the existence of enterprises, corporate annual net capital expenditure does not exceed the enterprise's annual operating profit after tax (EBIT 1-T).

In the phase of rapid growth, it is necessary to clear the prediction stage:

(1) Each used to calculate economic value added and corporate free cash flow are consistent with the after tax operating profit; (2) Each for the calculation is consistent in total investment capital of economic value added and corporate free cash flow;(3) weighted average cost of capital unchanged; (4) Consistent with the method of enterprise report prediction.

The phase of stable growth: (1) The enterprise operating profit after tax EBIT (1-T) at a fixed growth rate of $G$ growth; (2) The investment capital return rate unchanged before the enterprises to enter the stable growth period;(3)The enterprise each new capital investment return rate unchanged.

Second, enterprises in the future five years of free cash flow and economic value added are positive growth year by year, it reveals that the enterprise obtaining certain operating cash flow, while also creating value for the company. In this case, the enterprise should adopt a prudent financial strategy. In order to achieve steady growth in financial performance and asset size, 
optimize the allocation of resources and improve the utilization of existing resources as far as possible. Make the profit accumulation as the basic source of cash to expand the scale of enterprises, the distribution of cash dividends and so on. At this stage, the financial characteristics of enterprises are "moderate liabilities, middle income, appropriate dividend distribution".

Third, the enterprise value calculated by economic value added includes three parts: Capital investment in the early stage of enterprise, the first five years of the economic value added present value and the present value of all the economic value added after five years. And cash flow discount method includes two parts: the sum of the present value of corporate free cash flow in the first five years. The present value of free cash flow after five years, from this view, the value of the enterprise free cash flow discount method is predicted, therefore economic value added in the assessment of enterprise value is relatively low deviation rate[3].

Fourth, calculated and compared, discounted free cash flow model in a single year, as long as the change of the amount of investment can make the free cash flow and present value change. So free cash flow is easy to be manipulated[4]. If business managers want to change the free cash flow, he just needs to cancel or postpone a number of investments projects can be achieved, but it has a certain impact on the sustainable development of the enterprise's future. In the economic value added discount model, there is no direct relationship between the size of the annual investment amount before and after the enterprise and the economic value added of a single year, so the enterprise value calculated by economic value added is not easy to be manipulated, Accuracy is relatively high.

Fifth, the two models are simple to implement. Can be calculated by calculating the value of enterprises, it is conducive to the management and development of investors and management staff to measure the current and future operations and developments, and make a more optimized improvement and choice for future business and strategic investment.

\section{The Role of Free Cash Flow and Economic Value Added in Financial Strategy.}

In terms of financing strategy, the main goal of financing strategy is to reduce the cost of capital by determining the best structure, ensure maximum enterprise values, Companies tend to consider debt capital while ignoring equity capital. If the enterprise economic value added and cash flow are positive, the use of a stable financial strategy; economic value added is positive, cash flow statement is now a net outflow, the expansion of the use of financial strategy; economic value added is negative, cash flow to net inflows, adopt defensive financial strategy; economic value added and cash flows are negative. Enterprises are generally required to be merged or acquired or directly filed for bankruptcy.

In terms of investment strategy, when the value of project economic added greater than zero, so the enterprise can invest in this project. Meanwhile, economic value added marginal contribution to decision whether to invest in order to reduce the idle capacity of enterprises.

In terms of dividend distribution strategy, when economic value added greater than zero, the enterprise should reduce the dividend payment rate, using 0 dividend payout ratio or residual dividend policy. When economic value added less than zero, the enterprise should return the cash to shareholders, increase the dividend payout ratio. The size of the free cash flow determines the enterprise to adopt different dividend distribution policy.

\section{Model Improvement Suggestions}

The evaluation of enterprise value can reflect the economic situation and the future development trend of the enterprise. The evaluation of enterprise value is an important tool for enterprise managers to choose the strategic management of enterprises. Through the empirical research of the two models, it points out the defects of the model and puts forward some suggestions for improvement.

First of all, the main difference between the two methods is the cost of research and the construction of the two accounting subjects. The free cash flow discount model takes into account the operating cash flow of the enterprise in the current period, the research costs as expenses in the period decreased, and the new construction in the current period as a reduction of capital 
expenditures. Economic value added model is considered the future of the investment capacity of the enterprise, the research costs as a future capital increase in business investment, while the net value of construction in progress as a certain percentage of the capital increase.

For the free cash flow model, the free cash flow is in a static state, because the cash flow in real life is constantly changing, it is dynamic. The improvement suggestion is based on the original model, Plus the value adjustment factor. There are major issues to occur in the enterprise, and the enterprise value is expected to reduce the difference.

Economic value added is calculated using the historical cost of the asset, without taking into account the impact of inflation rate (IR). For economic value added this defect, therefore, the improvement suggestion is to set up a new ratio. According to Xiamen University Chen Zhao "enterprise value assessment" in the enterprise to enter the stable period of growth (g) is not always the same [5]. Suppose invested capital return on invested capital unchanged for R1and enterprise each new capital return rate unchanged for the $R \mathrm{c}$, that $E V A t+1 / E V A t=1+g \times(1-r / R c) /(1-r / R t)-I R$. So put forward to adjust the ratio: $(\mathrm{AR})=$ economic value added growth rate - inflation rate. that is $A R=\mathrm{g} \times(1-r / R c) /(1-r / R t)-I R$. After calculating the economic value added, the economic value added value is obtained by adjusting the ratio after removing the inflation rate.

Finally, because the free cash flow model and the economic value added model to be used in weighted average cost of capital discounted. However, due to the determination of weighted average cost of capital complicated. In order to simplify the calculation of enterprise value, weighted average cost of capital simplification is also a very important part of.

The deficiency of this article is to make the enterprise development forecast in the process of calculating enterprise value, although it bases on a number of national policies and development stage of the enterprise. But there will still be some subjectivity, as a result, there is a certain gap with reality.

\section{References}

[1] Meilin Ni, Evaluation of EVA enterprise value, Finance and Economic University of Tianjin, 2009.

[2] Jing Shi, Study on enterprise value evaluation based on cash flow discount method, Beijing Jiaotong University, 2009.

[3] Xiangtie Hong, Changxing Guo. The application of discounted cash flow method to assess the company's strategic. Journal of Science of Teachers' College and University, 2015.

[4] Jianhua Zhao, "The advantage of economic value added (EVA) in the evaluation of enterprise value —Comparison with free cash flow as evaluation criteria”, Henan Social Science, 2007, pp.69-70.

[5] Ronghua Yang, Zhi Huang , Environmental uncertainty, financial flexibility and firm value -Based on the empirical evidence of A share listed companies in 2008-2014,Communication of Finance and Accounting , 2016, pp.27-31. 